\title{
Assessment of Genetic Stability of Micropropagated Curcuma caesia through Cytophotometric and Molecular Analysis
}

\author{
S. Mohanty ${ }^{1}$, R. K. Joshi ${ }^{1}$, E. Subudhi ${ }^{1}$, S. Sahoo ${ }^{2}$ and S. Nayak ${ }^{1, *}$ \\ ${ }^{1}$ Centre of Biotechnology, Siksha O Anusandhan University, \\ Khandagiri, Bhubaneswar-30, Orissa, India \\ ${ }^{2}$ P.G. Department of Botany, Utkal University, Vanivihar, \\ Bhubaneswar, Orissa, India
}

Received January 21, 2010; accepted February 1, 2010

\begin{abstract}
Summary Protocol has been standardized for micropropagation of medicinally important Curcuma caesia using sprouted bud explants from rhizome. Tissue culture raised plantlets of $C$. caesia could be conserved in vitro through subculturing at an interval of 4 months. The genetic stability of micropropagated plants was studied with an interval of 6 months up to 30 months in culture using cytophotometric, random amplified polymorphic DNA (RAPD) and inter simple sequence repeats (ISSR) analysis. Cytophotometric analysis of 151 plants revealed a unimodal distribution of the DNA content with a peak corresponding to 4C nuclear DNA (3.5 pg). RAPD and ISSR analysis revealed mopnomorphic bands showing the absence of polymorphism in all 73 regenerants analyzed, thus confirming the genetic uniformity among in vitro grown somaclones of Curcuma caesia.
\end{abstract}

Key words Curcuma caesia, Cytophotometric analysis, Genetic stability, Micropropagation, Molecular marker.

Curcuma caesia Roxb., commonly known as black turmeric is a wild species of the family Zingiberaceae. C. caesia is known especially in North East India and Bangladesh. It is rarely found in other parts of India, such as Madhya Pradesh, Jharkhand, Chattisgarh, and Orissa. Rhizomes of the plant are used for sprains and bruises, and are also employed as cosmetics (CSIR 1962). It is also used as a carminative, and for the treatment of headaches and rheumatic pains. The rhizomes are aromatic and yield an essential oil. The inner part of the rhizome is bluish-black in colour and emits a characteristic sweet smell due to the presence of essential oil. The oils possess antibacterial and antifungal properties (Rahman and Yusuf 1996) and are claimed to be useful in treating piles, leprosy, bronchitis, asthma, cancer, epilepsy, fever, wounds, impotency and migraines etc. A paste made from the rhizome is used to cure blood dysentery and as poultice in rheumatic pain. The leaves are used as a wrapping material and dry leaves are used as fuel by Bengalis in Bangladesh (Yusuf et al. 2002). North Indian tribes use black turmeric as a talisman to keep the evil spirits away. This plant is in great demand in Central India and due to indiscriminate exploitation without ensuring its regeneration and conservation, the plant has recently been categorized as an endangered species (Kumar 1998). This necessitates the application of the tissue culture technique for micropropagation and in vitro conservation of $C$. caesia and to ensure genetic stability for production of true-to-type plantlets.

The tissue culture technique is a powerful tool which can be employed as an alternative to the conventional method of vegetative propagation with the objective of rapid clonal multiplication of desired genotypes (Hussey 1986, Murashige and Skoog 1990). Periodic monitoring of the degree of

* Corresponding author, e-mail: sanghamitran@yahoo.com 
genetic stability of in vitro conserved plants is of utmost importance for commercial utilization of the technique for large scale production of true-to-type plants of the desired genotype. The assessment of the genetic integrity of in vitro grown regenerants at regular intervals can significantly reduce or eliminate the chance of occurence of somaclonal variations (Larkins and Scowcroft 1981) at the early or late phase of culture. Cytophotometric analysis is very useful for quick determination of the extent of the ploidy level of regenerated plants with a large number of cells (Nayak and Sen 1995). Of several molecular markers used for the assessment of genetic stability, RAPD and ISSR analysis are the simplest, cheapest and quickest method for determining the genetic fidelity of in vitro grown plants as reported in many species (Williams et al. 1990, Rout et al. 1998, Martins et al. 2004, Venkatachalam et al. 2007, Joshi and Dhawan 2007). Although micropropagation and in vitro conservstion of C. caesia has been reported (Balachandran et al. 1990, Raju et al. 2005, Tyagi et al. 2004), there is no report regarding the extent of stability of the micropropagated clones.

We report rapid in vitro multiplication of C..caesia and in vitro monitoring of the genetic stability of micropropagated plants through cytophotometric estimation of the 4C nuclear DNA content RAPD and ISSR analysis at regular intervals. This will definitely meet the increasing demand of this endangered species with its conserved genetic integrity.

\section{Materials and methods}

\section{Plant material}

Rhizome of C. caesia was collected from a high altitude research station in Pottangi, Koraput, Orissa, and was grown in the medicinal plant garden of the Centre of Biotechnology, Bhubaneswar, Orissa (India). Rhizomes containing sprouted apical buds were used as explants and were thoroughly washed with water. The explants were kept under running water for 10-15 min and then dipped in liquid detergent (Extran, Merck) for 3-5 min. They were thoroughly washed with distilled water to remove the last drop of detergent. Surface sterilization was done by $0.1 \%$ mercuric chloride solution for 8-12 min depending upon the nature and size of the explants. After sterilization the explants containing buds were washed several times with sterile distilled water under aseptic conditions prior to inoculation.

\section{In vitro multiplication}

Explants were inoculated to the basal medium of Murashige and Skoog (MS) (1962) with varying combinations of benzyl adenine $(1-5 \mathrm{mg} / \mathrm{l})$, indole-3-acetic acid $(0.5-2 \mathrm{mg} / \mathrm{l})$, naphthalene acetic acid $(0.5-2 \mathrm{mg} / \mathrm{l})$ and kinetine $(0.5-2 \mathrm{mg} / \mathrm{l})$. fifteen replicas were used for each treatment. The MS media was gelled with $0.8 \%(\mathrm{~m} / \mathrm{v})$ agar (Himedia Laboratories Pvt. Ltd., Mumbai, India) and sterilized at $121^{\circ} \mathrm{C}$ and $1.06 \mathrm{~kg} / \mathrm{cm}^{2}$ pressure for $15 \mathrm{~min}$. The $\mathrm{pH}$ of the media was adjusted to 5.73-5.74. After sterilization of the media, the explants were inoculated into the medium. The explants were inoculated under aseptic conditions and then kept in a culture room under white fluorescent light of $50 \mu \mathrm{mol} \mathrm{m}^{-2} \mathrm{~s}^{-1}$ for $16 \mathrm{~h}$ photoperiod. The temperature of the culture room was maintained at $25 \pm 2{ }^{\circ} \mathrm{C}$. Explants with well developed shoots and roots were subcultured at an interval of 3-4 months in culture. Each individual shoot was separated and inoculated to a fresh media for further growth. In vitro grown plantlets with well developed shoots and roots were transferred to pots containing sterilized soil. These were then kept in a greenhouse for acclimatization. After 1 month they were transferred to normal field conditions and grown to maturity.

\section{Cytophotometric analysis}

For cytophotometric analysis, explants' tissue was collected from a field-grown source plant 
and the root tips of in vitro grown regenerants aseptically from culture tubes and fixed over night in propionic acid/ethanol $(1: 3)$. This treatment was followed by hydrolysis in $1 \mathrm{M} \mathrm{HCl} \mathrm{(v/v)} \mathrm{at} 60^{\circ} \mathrm{C}$ for $12 \mathrm{~min}$. The root tips were washed in distilled water, stained in Schiff's reagent for $2 \mathrm{~h}$ at $14^{\circ} \mathrm{C}$ and squashed with $45 \%$ acetic acid. The DNA content of nuclei was measured with a Leitz Wetzlar micro-spectrophotometer using the single wavelength $(550 \mathrm{~nm})$ method (Sharma and Sharma 1980). In situ DNA values were obtained on the basis of optical densities which were converted to picograms (pg) by using 4C nuclear DNA value of Allium cepa (67.1 pg) as standard (Van't Hof 1965).

\section{Isolation of DNA}

Fresh young leaves were collected and washed thoroughly with cold autoclaved distilled water, then blotted to dry. About $2 \mathrm{~g}$ of leaves were taken for extraction. The genomic DNA was isolated following the protocol of Doyle and Doyle (1990) with a little modification; insoluble polyvinylpolypyrolidone was added to the leaf sample prior to grinding. The crude DNA was purified with RNase A $(60 \mu \mathrm{g} / \mathrm{ml}$ of crude DNA solution) followed by washing thrice with phenol/chloroform/isoamyl alcohol $(25: 24: 1 \mathrm{v} / \mathrm{v} / \mathrm{v})$ and subsequently with chloroform/isoamylalcohol $(24: 1 \mathrm{v} / \mathrm{v})$. Quantification of DNA was done by $0.8 \%$ agarose gel electrophoresis of the samples along with a known amount of uncut lambda DNA (Bangalore Genei Pvt. Ltd, Bangalore, India) as standard. DNA samples were diluted to $25 \mathrm{ng} / \mu \mathrm{l}$ for RAPD-PCR analysis.

\section{RAPD and ISSR analyses}

For RAPD analysis a total of 30 random primers were used out of which 19 random decamer primers (Operon Tech, Almeda, USA) were selected. In the case of ISSR, out of 10 primers, 8 were selected. The RAPD analysis was performed as per the method of Williams et al. (1990) and for ISSR analysis the method of Zeitkiewicz et al. (1994) was followed. RAPD and ISSR amplifications were performed routinely using a PCR mixture $(25 \mu \mathrm{l})$ containing $25 \mathrm{ng}$ of genomic DNA as a template, $10 \times$ PCR buffer (Bangalore Genei, India), $200 \mu \mathrm{M}$ dNTPs (Bangalore Genei, India ), 0.5 unit (U) of Taq polymerase (Bangalore Genei, India), and $15 \mathrm{ng}$ of RAPD primer or $40 \mathrm{ng}$ of ISSR primer. The amplification was carried out in a thermal cycler (Gene Amp PCR system 9700, Applied Biosystems, CA, USA). In RAPD, PCR was performed at an initial temperature of $94^{\circ} \mathrm{C}$ for $5 \mathrm{~min}$ for complete denaturation. The second step consisted of 42 cycles having 3 ranges of temperature, i.e. at $92^{\circ} \mathrm{C}$ for $1 \mathrm{~min}$ for denaturation of template DNA, at $37^{\circ} \mathrm{C}$ for $1 \mathrm{~min}$ for primer annealing, at $72^{\circ} \mathrm{C}$ for $2 \mathrm{~min}$ for primer extension, followed by running the samples at $72^{\circ} \mathrm{C}$ for $7 \mathrm{~min}$ for complete polymerization. For ISSR the same temperature profile was followed, but the primer annealing temperature was set at $5^{\circ} \mathrm{C}$ lower than the melting temperature. The PCR products obtained from RAPD were analyzed in $1.5 \%$ agarose gel whereas the ISSR products were analyzed in $2 \%$ agarose gel stained with ethidium bromide $\left(0.5 \mu \mathrm{g} \mu \mathrm{l}^{-1}\right)$. The size of the amplicons was estimated using $100 \mathrm{bp}$ DNA ladder plus or DNA ladder mix (MBI Fermentas, Lithuania) and documented in the Gel Doc (Bio-Rad, USA).

\section{Results}

\section{In vitro multiplication}

Sprouted rhizome buds of $C$. caesia were cultured as explants (Fig. 1A) on MS media with various combinations of BA (1-5 mg/l), IAA $(0.5-2 \mathrm{mg} / \mathrm{l})$, NAA $(0.5-2 \mathrm{mg} / \mathrm{l})$ and Kinetin $(0.5-2 \mathrm{mg} / \mathrm{l})$. The percentage of explants forming shoots was maximum in media with BA ( $3 \mathrm{mg} / \mathrm{l})$ and IAA $(0.5 \mathrm{mg} / \mathrm{l})$ i.e., $92.8 \pm 0.3$ (Table 1). A higher concentration of BA showed less response towards in vitro shoot initiation. Media with BA $(1 \mathrm{mg} / \mathrm{l})$ and IAA $(0.5 \mathrm{mg} / \mathrm{l})$ was optimum for in vitro shoot multiplication with $3.5 \pm 0.2$ number of shoots and $1.1 \pm 0.2$ number of roots (Fig. 1B, C). Media with BA and NAA were also effective for shoot initiation and multiplication. Media with 

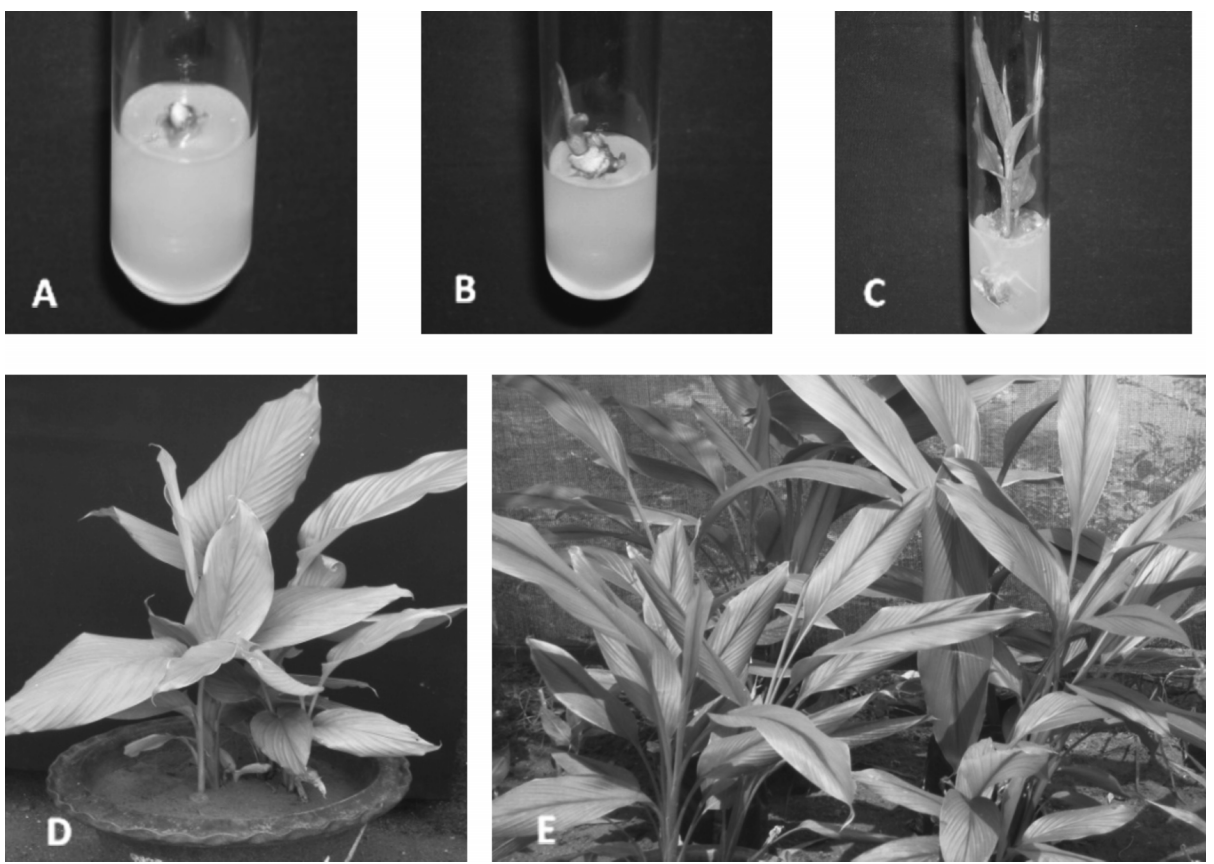

Fig. 1. (A) Sprouted bud explant of C. caesia. (B) Induction of multiple shoots in C. caesia. (C) In vitro Multiplication in C. caesia. (D) Potted plant. (E) Micropropagated plants of C. caesia growing under field conditions.

Table 1. In vitro shoot multiplication of C. caesia on MS medium fortified with different growth regulators

\begin{tabular}{|c|c|c|c|c|c|c|c|}
\hline \multirow{2}{*}{ S1. No. } & \multicolumn{4}{|c|}{ MS media with growth regulators (mg/l) } & \multirow{2}{*}{$\begin{array}{c}\% \text { of } \\
\text { shoot } \\
\text { initiation }\end{array}$} & \multirow{2}{*}{$\begin{array}{l}\text { No of shoots } \\
\text { per explants } \\
(\text { Mean } \pm S E)\end{array}$} & \multirow{2}{*}{$\begin{array}{l}\text { No of roots } \\
\text { per explants } \\
(\text { Mean } \pm \text { SE) }\end{array}$} \\
\hline & BA & IAA & NAA & $\mathrm{Kn}$ & & & \\
\hline 1 & 1 & - & - & - & $30.6 \pm 0.5$ & $0.6 \pm 0.2$ & $0.5 \pm 0.2$ \\
\hline 2 & 3 & - & - & - & $71.7 \pm 0.3$ & $1.2 \pm 0.1$ & $1.5 \pm 0.2$ \\
\hline 3 & 5 & - & - & - & $61.5 \pm 0.4$ & $1.8 \pm 0.3$ & $1.4 \pm 0.2$ \\
\hline 4 & 1 & 0.5 & - & - & $76.1 \pm 0.5$ & $3.5 \pm 0.2$ & $1.1 \pm 0.2$ \\
\hline 5 & 3 & 0.5 & - & - & $92.8 \pm 0.3$ & $3.2 \pm 0.2$ & $2.1 \pm 0.1$ \\
\hline 6 & 5 & 0.5 & - & - & $66.1 \pm 0.6$ & $2.1 \pm 0.3$ & $1.0 \pm 0.3$ \\
\hline 7 & 1 & - & 0.5 & - & $71.7 \pm 0.7$ & $1.5 \pm 0.2$ & $1.5 \pm 0.3$ \\
\hline 8 & 3 & - & 1 & - & $54.8 \pm 0.5$ & $1.2 \pm 0.1$ & $1.2 \pm 0.1$ \\
\hline 9 & 1 & - & & 0.5 & $43.4 \pm 0.7$ & $1.1 \pm 0.1$ & $2.5 \pm 0.2$ \\
\hline 10 & 3 & - & & 1 & $54.7 \pm 0.6$ & $1.1 \pm 0.1$ & $2.1 \pm 0.2$ \\
\hline 11 & 1 & 0.5 & 0.5 & - & $38.7 \pm 0.4$ & $1.1 \pm 0.3$ & $2.1 \pm 0.3$ \\
\hline 12 & 3 & 1 & 1 & - & $64.2 \pm 0.6$ & $1.4 \pm 0.2$ & $2.4 \pm 0.2$ \\
\hline
\end{tabular}

The differences in mean values among the treatments are statistically significant $(p<0.05)$. Data represents the mean of 15 replicates for each treatment.

BA $(1 \mathrm{mg} / \mathrm{l})$ and NAA $(0.5 \mathrm{mg} / \mathrm{l})$ showed $71.7 \pm 0.7$ percentage of shoot initiation with $2.5 \pm 0.2$ number of shoot and $1.5 \pm 0.2$ number of roots. The number of shoots decreases with the increase in concentration of BA and NAA. Kinetin alone had no role in shoot multiplication.

\section{Establishment of plants in soil}

Plants with well developed shoots and roots (Fig. 1D) were then transferred to pots and grown 
in green house for 1 month for acclimatization. After 1 month the acclimatized plants were transferred to the field and were established showing a survival rate of $90 \%$ (Fig. 1E).

\section{Cytophotometric analysis}

Cytophotometric analysis of the original explant was carried out before explantation which revealed a peak showing $2 \mathrm{C}$ value $(1.7 \mathrm{pg})$. The cytophotometric analysis of the $4 \mathrm{C}$ nuclear DNA content of root tips from a total of 151 in vitro grown regenerants, carried out at 6 month, intervals up to 24 months in culture, revealed diploidy in all with a unimodal distribution with 1 distinct peak corresponding to a $4 \mathrm{C}$ value $(3.5 \mathrm{pg})$. This is the same same as obtained in the source plant. The range of mean DNA content in root tips of in vitro conserved plantlets of different ages was almost similar to the range obtained in root tips of 10 control plants from the field (Table 2). The plantlets of $C$. caesia used for the cytophotometric study were labeled properly to be used for the molecular analysis with RAPD and ISSR markers.

Table 2. Nuclear DNA content of in vitro grown plantlets of C. caesia at different culture periods

\begin{tabular}{lccc}
\hline \multicolumn{1}{c}{$\begin{array}{c}\text { Period of } \\
\text { culture }\end{array}$} & $\begin{array}{c}\text { No } \\
\text { of plants } \\
\text { Analyzed }\end{array}$ & $\begin{array}{c}\text { Ploidy } \\
\text { status of } \\
\text { regenerants }\end{array}$ & $\begin{array}{c}\text { Range of } \\
\text { mean DNA } \\
\text { Content (pg) }\end{array}$ \\
\hline Control from field & 10 & Exclusively diploid & $3.52-3.61$ \\
3 months & 25 & Exclusively diploid & $3.54-3.58$ \\
6 months & 32 & Exclusively diploid & $3.51-3.60$ \\
12 months & 28 & Exclusively diploid & $3.52-3.62$ \\
24 months & 31 & Exclusively diploid & $3.55-3.59$ \\
30 months & 35 & Exclusively diploid & $3.53-3.61$ \\
\hline
\end{tabular}

\section{RAPD and ISSR analyses}

RAPD and ISSR analysis was done up to 30 months in a interval of 6 months. In Curcuma caesia, out of 25 RAPD primers 19 primers were selected and gave a total of 82 bands ranging from $320-3000 \mathrm{bp}$. The number of bands in all primers varied from 1-10 with an average of 4.3 bands per primer. All the bands were monomorphic, showing no polymorphism among 73 plants analyzed up to 24 months of culture (Fig. 2A). The number of
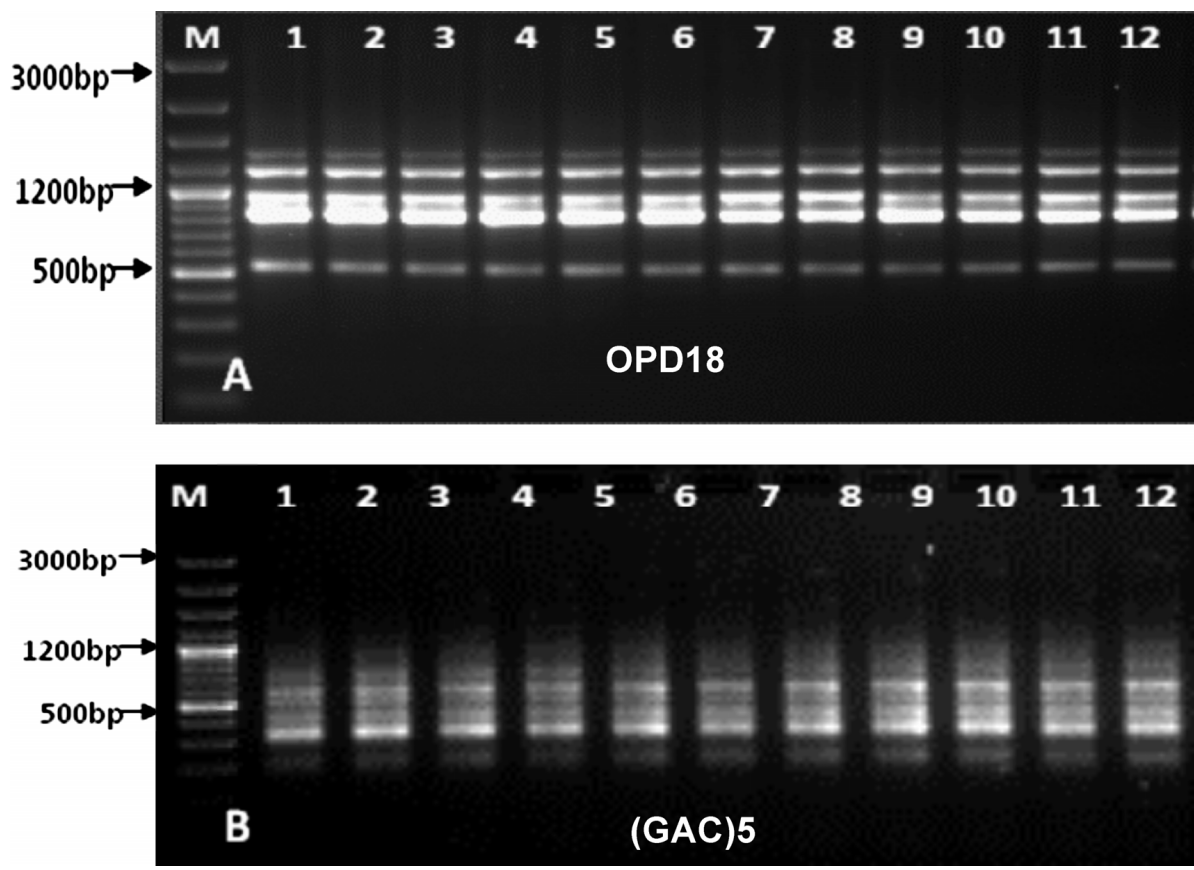

Fig. 2. (A) RAPD and (B) ISSR banding pattern in both micropropagated and field grown mother plants of C. caesia (Lane 1, mother plant; Lane 2-12 micropropagated plants). 
Table 3. RAPD and ISSR banding pattern of micropropagated and field-grown mother plants of C. caesia

\begin{tabular}{|c|c|c|c|c|}
\hline & Primer & Sequence & Total bands & $\begin{array}{c}\text { Range of } \\
\text { amplicons [bp] }\end{array}$ \\
\hline \multirow[t]{19}{*}{ RAPD } & OPA4 & AATCGGGCTG & 6 & $320-1500$ \\
\hline & OPA7 & GAAACGGGTG & 2 & $600-2200$ \\
\hline & OPA9 & GGGTAACGCC & 5 & $850-1750$ \\
\hline & OPA18 & AGGTGACCGT & 3 & $450-900$ \\
\hline & $\mathrm{OPC} 2$ & GTGAGGCGTC & 6 & $650-1300$ \\
\hline & OPC5 & GATGACCGCC & 3 & $1031-1700$ \\
\hline & OPC11 & AAAGCTGCGG & 10 & $450-1900$ \\
\hline & OPD3 & GTCGCCGTCA & 2 & $800-1250$ \\
\hline & OPD7 & TTGGCACGGG & 8 & $450-2000$ \\
\hline & OPD8 & GTGTGCCCCA & 4 & $850-1700$ \\
\hline & OPD12 & CACCGTATCC & 1 & 850 \\
\hline & OPD18 & GAGAGCCAAC & 5 & $450-1031$ \\
\hline & OPD20 & ACCCGGTCAC & 6 & $600-3000$ \\
\hline & OPN4 & GACCGACCCA & 3 & $500-1200$ \\
\hline & OPN16 & AAGCGACCTG & 2 & $350-1031$ \\
\hline & OPN18 & GGTGAGGTCA & 2 & $400-1031$ \\
\hline & OPAF5 & CCCGATCAGA & 6 & $650-2200$ \\
\hline & OPAF14 & GGTGCGCACT & 3 & $900-3000$ \\
\hline & OPAF15 & CACGAACCTC & 5 & $550-2000$ \\
\hline \multicolumn{5}{|c|}{ Total 82} \\
\hline \multirow[t]{8}{*}{ ISSR } & SPS 1 & $(\mathrm{GAC}) 5$ & 12 & $200-1200$ \\
\hline & SPS 2 & (GTGC)4 & 6 & $300-1050$ \\
\hline & SPS 3 & $(\mathrm{GACA}) 4$ & 8 & $475-1900$ \\
\hline & SPS 4 & $(\mathrm{AGG}) 6$ & 8 & $400-1031$ \\
\hline & SPS 5 & (GA)9T & 5 & $350-975$ \\
\hline & SPS 6 & $\mathrm{~T}(\mathrm{GA}) 9$ & 7 & $500-1100$ \\
\hline & SPS 7 & (GTG)5 & 8 & $250-850$ \\
\hline & SPS 8 & (GGA)4 & 9 & $300-1500$ \\
\hline
\end{tabular}

monomorphic bands was highest, 10 in primer OPC11 (ranging from 450-1900 bp) and lowest, 1 in primer OPD12 $(850 \mathrm{bp})$. A total of 5986 bands [(number of plantlets analyzed) $\times$ (number of bands with all primers)] were generated by the RAPD techniques (Table 3). Out of 10 ISSR primers, 8 primers formed a total of 63 bands(ranging from 200-1900 bp) which are all monomorphic in nature. The number of bands varied from 5-12 in all primers with an average of 7.8 bands per primer. A total of 4599 bands [(number of plantlets analyzed) $\times$ (number of bands with all primers)] were generated by the ISSR techniques (Table 3). The highest number of bands i.e. 12 in primer (GAC)5 (ranging from 200-1200 bp), and lowest number of bands, i.e. 5 in primer (GA)9T (350-975 bp), were amplified by ISSR analysis.Thus no variation was detected among in vitro conserved plantlets (Fig. 2B).

In the present study, 2 PCR based molecular markers, RAPD and ISSR, were used to show the genetic integrity in micropropagated $C$. caesia because of their cost effectiveness and simplicity. As there was no variation in the banding pattern both in RAPD and ISSR in all the regenerants analyzed in comparison with the mother plants, we conclude that the protocol developed could be used as a method for large scale propagation of true-to-type plantlets and conservation of $C$. caesia in vitro. 


\section{Discussion}

In vitro multiplication of sprouted bud explants of $C$. caesia showed differential responses to MS media with various combinations of plant growth regulators. However BA had a marked effectiveness on multiplication. The role of BA in shoot multiplication has been reported in other Zingiberaceous species (Balachandran et al. 1990, Mohanty et al. 2008, Nayak 2000, Panda et al. 2007, Rout et al. 2002, Salvi et al. 2002). Development of roots occurred in the same media. This report is also in agreement with Tyagi et al. (2004). The plantlets could be conserved in MS media with BA $3 \mathrm{mg} / 1$ for more than 4 months whereas, according to Tyagi et al. (2004), kinetin was found to be optimum for the conservation of $C$. caesia. In our case, kinetin showed no such effect. This may be due to differences existing between $C$. caesia collected from different regions.

Somaclonal variation is a major problem associated with in vitro culture which arises as a direct consequence of in vitro culture of plant cell tissue and organs (Larkins and Scowcroft 1981). In our study we adopted the method of periodic assessment of micropropagated plants of $C$. caesia clones using cytophotometric, and RAPD and ISSR analysis to reduce the chance of induction of somaclonal variation at the early or late phase of culture.

Cytophotometric analysis of 4C nuclear DNA content of root tips of all regenerants at different culture periods revealed diploidy in all with a unimodal distribution of peak corresponding to a mean value of $4 \mathrm{C}$ nuclear DNA content $(3.5 \mathrm{pg})$, the same as that of the source plant. The original explants were subjected to cytophotometric analysis before explantation onto the media and revealed the presence of unimodal peak corresponding to $2 \mathrm{C}$ value in each case, thereby conferming the absence of polysomaty.

Extensive work has been done to facilitate the understanding of mechanisms leading to somaclonal variations, which include chromosomal rearrangements, single gene mutations and lead to stable mutations. Hirochika (1993) first reported the activation of retrotransposons leading to somaclonal variations due to TC-induced stress in tobacco. The sub- and supra-optimal levels of plant growth substances, especially synthetic ones, have also been associated with somaclonal variation (Martin et al. 2006). Somatic embryogenesis is usually considered best next to axillary multiplication as there is stringent genetic control throughout the somatic embryo formation and the selection pressure against the abnormal types is considerably high (Leroy et al. 2000). Other methods of regeneration, such as organogenic differentiation, are more prone to somatic variations. Shenoy and Vasil (1992) reported that micropopagation through explants containing organized meristem is generally associated with low risk of genetic instability. Hence, it becomes imperative to regularly check the genetic purity of the micropopagated plants in order to produce clonally uniform progeny while using different techniques of micropropagation.

In the present study, the length of culture period (for 30 months) did not seem to affect their genetic stability. Some authors have reported that the time in in vitro culture could promote somaclonal variation (Hartmann et al. 1989, Nayak and Sen 1991), whereas Gould (1986) has reported that culture time does not seem to be the only parameter affecting genetic stability. Genetic variation in a culture line could be affected more by a genotype than by the period in culture (Hammerschlag et al. 1987, Nayak and Sen 1998, Vendrame et al. 1999).

In the present study, RAPD and ISSR markers were chosen because of their simplicity and cost-effectiveness. The use of 2 types of markers which amplify different regions of the genome allow better analysis of genetic stability/variation of the plantlets (Martins et al. 2004, Venkatachalam et al. 2007). In the present study, RAPD and ISSR analysis of in vitro conserved $C$. caesia showed a profile similar to that of the control, indicating that no genetic variation had occurred in vitro. This confirmed the genetic integrity by RAPD and ISSR analysis that had been reported earlier in many species (Bhatia et al. 2009, Joshi and Dhawan 2007, Mohanty et al. 2008, Panda et al. 2007, Rout et al. 2002, Venkatachalam et al. 2007, Salvi et al. 2002, Martins et al. 
2004). Our study, in close agreement with Zuchi et al. (2002), reveals that the absence of polymorphism in micropropagated $C$. caesia could be due to the absence of polymorphism in source plants.

\section{Acknowledgements}

The authors are grateful to Dr. S. C. Si, Dean, Centre of Biotechnology and Dr. M. R. Nayak, President, Siksha $\mathrm{O}$ Anusandhan University for providing facilities and encouragement throughout. Financial assistance from Department of Biotechnology, New Delhi, India, is also duly acknowledged.

\section{References}

Balachandran, S. M., Bhat, S. R. and Chandel, K. P. S. 1990. In vitro clonal multiplication of turmeric (Curcuma longa) and ginger (Zingiber officinale Rosc.). Plant Cell Rep. 3: 521-524.

Bhatia, R., Singh, K. P., Jhang, T. and Sharma, T. R. 2009. Assesment of genetic fidelity of micropropagated gerbera plants by ISSR markers. Sci. Hortic 11: 208-211.

CSIR (ed.). 1962. The Wealth of India, Raw Materials. CSIR, New Delhi. p. 402.

Doyle, J. J. and Doyle, J. L. 1990. A rapid DNA isolation procedure for small quantities of fresh leaf tissue. Phytochem. Bull. 19: 11-15.

Gould, A. R. 1986. Factors controlling generation of variability in vitro. In: Vasil, I. K. (ed.). Cell culture and somatic cell genetics in plants. 3. Plant regeneration and genetic variability. Academic, Orlando. pp. 549-567.

Hammerschlag, F. A., Bauchan, G. R. and Scorza, R. 1987. Factors influencing in vitro multiplication and rooting of peach cultivars. Plant Cell Tissue Organ Cult. 8: 235-242.

Hartmann, C., Henry, Y., De Buyser, J., Aubry, C. and Rode A. 1989. Identification of new mitochondrial genome organizations in wheat plants regenerated from somatic tissue cultures. Theor. Appl. Genet. 77: 169-175.

Hirochika, H. 1993. Activation of tobacco transposons during tissue culture. EMBO J. 12: 2521-2528.

Hussey, G. 1986. Problems and prospects in the in vitro propagation of herbaceous plants. In: Withers L. A. and Aldeson P. G. (eds.). Plant Tissue Culture and its Agricultural Application. Butterworths, London. pp. 113-123.

Joshi, P. and Dhawan, V. 2007. Assesment of genetic fidelity of micropropagated Swertia chirayita plantlets by ISSR marker assay. Biol Plant. 51: 22-26.

Kumar, S., Singh, J., Shah, N. C. and Ranjan, V. 1998. Indian Medicinal Plants Facing Genetic Erosion. CIMAP, Lucknow. p. 219.

Larkins, P. and Scowcroft, W. R. 1981. Somaclonal variation, a novel source of variability from cell cultures for plant improvement. Theor. Appl. Genet. 60: 197-214.

Leroy, X. J., Leon, K., Charles, G. and Branchard, M. 2000. Cauliflower somatic embryogenesis and analysis of regenerant stability by ISSRs. Plant. Cell. Rep. 19: 1102-1107.

Martin, K. P., Pachathundkandi, S. K., Zhang, C. L. and Slater, A. 2006. RAPD analysis of a variant of Banana (Musa sp.) cv. Grande Naine and its propagation via shoot culture. In Vitro Cell Dev. Biol. 42: 188-192.

Martins M., Sarmento D. and Oliveira M. M. 2004. Genetic stability of micropropagated almond plantlets, as assessed by RAPD and ISSR markers. Plant Cell Rep. 23: 492-496.

Mohanty, S., Panda, M. K., Subudhi, E., Acharya, L. and Nayak, S. 2008. Genetic Stability of Micropropagated Ginger Derived from Axillary Bud through Cytophotometric and RAPD Analysis. Z Naturforsch. 63c: 747-754.

Murashige, T. and Skoog, N. S. 1990. Plant propagation by tissue culture. A practice with unrealized potential. In: Anmirato, P. V., Even, D. R., Sharp, W. R. and Bajaj. Y. P. S. (eds.). Handbook of Plant Cell Culture, McGraw Hill Publishing Company, New York. pp. 3-9.

- and Skoog, F. 1962. A revised medium for rapid growth and bioassays with tobacco tissue culture. Physiol Plant. 15: $473-479$.

Nayak, S. and Sen, S. 1991. Cytological and cytophotometric analysis of direct explant and callus derived plants of Ornithogalum thyrsoides Jacq. Cytologia. 56: 297-302.

— and - 1995. Rapid and stable propagation of Ornithogalum umbelatum L. in long term culture. Plant Cell Rep. 15: $150-153$.

— and - 1998. Differential resistance of three species of Ornithogalum to polyploidization in vitro. Nucleus. 41: 48-52.

- 2000. In vitro multiplication and microrhizome induction in Curcuma aromatica Salisb. Plant Growth Regul. 32: 41-47.

Panda, M. K., Mohanty, S., Subudhi, E., Acharya, L. and Nayak, S. 2007. Assessment of genetic stability of micropropagated plants of Curcuma longa L. by cytophotometry and RAPD analysis. Int. J. Integ. Biol. 1: 
189-195.

Rahman, M. A. and Yusuf, M. 1996. Diversity, Ecology and Ethnobotany of the Zingiberaceae of Bangladesh. J. Econ. Taxon. Bot. Addl. Series. 12: 13-19.

Raju, B., Anita, D. and Kalita, M. C. 2005. In vitro clonal propagation of Curcuma caesia Roxb, and Curcuma zedoaria Rosc. from rhizome bud explants. J. Plant Biochem Biotechnol. 14: 61-63. (eds.).

Rout, G. R. and Das, P. 2002. In vitro studies of ginger: A review of recent progress In: Goril J. N., Anand Kumar P. and Singh V. K. (eds.). recent progress is Medicinal Plants, Vol. 4-Biotechnology and Genetic Engineering, Science Technology Publication, city. pp. 307-326.

—, Das, P., Goel, G. and Raina, S. N. 1998. Determination of genetic stability of micropropagated plants of ginger using Random Amplified Polymorphic DNA (RAPD) markers. Bot. Bull. Acad. Sinica (Taiwan) 39: 23-27.

Salvi, N. D., George, L. and Eapen, S. 2002. Micropropagation and field evaluation of micropropagated plants of turmeric. Plant Cell Tissue Organ Cult. 68: 143-151.

Sharma and Sharma 1980

Shenoy, V. B. and Vasil, I. K. 1992. Biochemical and molecular analysis of plants derived from embryogenic tissue cultures of napiergrass (Penisetum purpureum K. Schum.). Theor Appl Genet. 83: 947-955.

Shirin, F., Kumar, S. and Mishra, Y. 2000. In vitro plantlet production system for Kaempferia galanga, a rare Indian medicinal herb. Plant Cell Tissue Organ Cult. 63: 193-197.

Tyagi, R. K., Yusuf, A., Dua, P. and Agrawal, A. 2004. In vitro plant regeneration and genotype conservation of eight wild species of Curcuma. Biol. Plant. 48: 129-132.

Van't Hof, J. 1965. Relationships between mitotic cycle duration, S period duration and the average rate of DNA synthesis in the root meristem cells of several plants. Exp. Cell Res. 39: 48-58.

Vendrame, W. A., Kochert, G. and Wetzstein, H. Y. 1999. AFLP analysis of variation in pecan somatic embryos. Plant Cell Rep. 18: 853-857.

Venkatachalam et al. 2007

Williams, J. G. K., Kubelik, A. R., Liva, K. J., Rafalski, J. A. and Tingey, S. V. 1990. DNA polymorphisms amplified by arbitrary primers are useful as genetic markers. Nucl. Acid Res. 18: 6531-6535.

Yusuf, M., Rahman, M. A., Chowdhury, J. U. and Begum, J. 2002. Indigenous knowledge about the use of Zingibers in Bangladesh. J. Econ. Taxon. Bot. 26: 566-570.

Zeitkiewicz, E., Rafalski, A. and Labuda, D. 1994. Genome finger printing by simple sequence repeat (SSR)-anchored PCR amplification. Genomics 20: 176-183.

Zucchi, M. I., Arizono, H., Morais, V. I., Fungaro, M. H. P., Vieira, and M. L. C. 2002. Genetic instability of sugarcane plants derived from meristem cultures. Genet. Mol. Biol. 25: 91-96. 